\title{
ACKNOWLEDGMENTS FOR THE FIRST EDITION
}

The authors are grateful to many persons and several organizations for much generous cooperation in producing this handbook--selecting lists of species to include, reviewing the manuscript, and lending or permitting use of illustrations.

GEOLOGICAL HISTORY: C. G. Higgins (review). WEATHER DATA ON PLANT BELTS: P. A. Munz and D. D. Keck. FUNGI: R. T. Orr (list, review, photographs); and University of California Herbarium, Berkeley (Elizabeth Morse negatives). LICHENS: J. W. Thomson and Isabelle Tavares (identifications). FERNS: Figures from Leroy Abrams. 1926-1960. Illustrated Flora of the Pacific States. Stanford, CA: Stanford University Press.

WILDFLOWERS AND SHRUBS: J. T. Howell (lists); J. M. Tucker (review); June McCaskill (identifications); figures from L. Abrams and R. S. Ferris. 1926-1960. Flora; a few from N. L. Britton and Addison Brown. 1913. An Illustrated Flora of the Northern United States and Canada. $2 \mathrm{~d}$ ed. By permission of New York Botanical Garden; color slides (besides those of the authors): California Academy of Sciences (Charles Webber collection); Sierra Club; Yosemite National Park Museum; E. O. Essig; and T. H. Jukes.

TREES: Figures from W. L. Jepson. 1923. Trees of California. Berkeley, CA: Sather Gate Bookshop; G. B. Sudworth. 1908. Forest Trees of the Pacific Slope. Washington, DC: USDA Forest Service; and L. Abrams and R. S. Ferris. 1926-1960. Flora.

miscellaneous animals: Some figures from T. I. Storer and R. L. Usinger. 1957. General Zoology. 3d ed. New York: McGraw-Hill Book Co. By permission of the publishers.

Moluusks: Allyn G. Smith (list, review, specimens for figures).

INSECTS: Arthur C. Smith and Jerry Powell (review); Frieda L. Abernathy, Celeste Green, and other persons in Department of Entomology, University of California, Berkeley; T. I. Storer and R. L. Usinger, 1957. General Zoology; and R. L. Usinger. 1956. Aquatic Insects of California. Berkeley and Los Angeles: University of California Press; some photos of insect work from Pacific Southwest Forest and Range Experiment Station, Berkeley.

FISHES: W. I. Follett (list, distributional data, review); California Department of Fish and Game (three color plates); other figures from scientific papers.

AMPHibians AND REPTILES: R. C. Stebbins (list, review, figures) from his Amphibians and Reptiles of Western North America. 1954. New York: McGraw-Hill Book Co. By permission of the publishers. 
BIRDS: R.T. Orr (list); L. H. Miller (review); Yonekichi Makino (line figures); Museum of Vertebrate Zoology, University of California, Berkeley; owl figures and color plates from J. Grinnell and T. I. Storer. 1924. Animal Life in the Yosemite. Berkeley: University of California Press; and Edward Spaulding color plate of red finches and Leucosticte used in Ralph Hoffman. 1927. Birds of the Pacific States. Boston: Houghton Mifflin Co. By permission.

mammaLs: R. T. Orr (list); L. P. Tevis, Jr. (review); Museum of Vertebrate Zoology, University of California, Berkeley (color plate of chipmunks); plate of mammal tracks adapted in part from W. H. Burt and R. P. Grossenheider. 1964. A Field Guide to the Mammals. 2d ed. By permission of W. H. Burt; and Emily E. Reid, Don G. Kelley, and Julia P. Iltis (line figures).

Other drawings made by Emily E. Reid, Julia P. Iltis, Barbara Daly, Paul Catts, and Petr Wygodzinsky.

Tracy I. Storer

Robert L. Usinger 